\title{
Gastric lipoma and pyloric obstruction in a 51-year-old woman
}

\section{Lipoma gástrico y obstrucción pilórica en una mujer de 51 años}

\author{
W.S. Furtado ${ }^{1}$ D.A.C.P.G. Mello ${ }^{1}$, V.M. Santos ${ }^{2}$, T.L. Bringel ${ }^{1}$, W.P. Oliveira Junior ${ }^{1}$, \\ H.J.L. Moura' ${ }^{\prime}$
}

\begin{abstract}
Gastric lipoma is considered a rare condition that may constitute a challenging diagnosis. A 51-year-old woman presented dysphagia and abdominal pain, and an upper digestive endoscopic study disclosed a gastric tumor located in the submucosa of the pyloric antrum. Conclusive diagnosis was established after repeated endoscopic biopsies, and the patient was subjected to an atypical gastrectomy, which evolved into a pyloric stenosis. This complication was appropriately corrected and the patient remains symptomless, under outpatient surveillance.
\end{abstract}

Key words. Atypical gastrectomy. Benign tumor. Gastric lipoma. Pyloric obstruction.

\section{RESUMEN}

Lipoma gástrico es un hallazgo muy raro que suele constituir un desafío diagnóstico. Una mujer con 51 años presentó disfagia y dolor abdominal; en una endoscopia digestiva superior se encontró un tumor gástrico submucoso localizado en el antro pilórico. Se hicieron biopsias endoscópicas para establecer el diagnóstico. Esta paciente se sometió a una gastrectomía atípica, que ocasionó estenosis del píloro. Esta complicación fue adecuadamente tratada, y la paciente se mantiene sin síntomas con control ambulatorio.

Palabras clave. Gastrectomía atípica. Lipoma gástrico. Obstrucción pilórica. Tumor gástrico benigno.
1. General Surgery Division of Armed Forces Hospital, Brasília-DF, Brazil

2. Catholic University Medical Course and Internal Medicina Department of Armed Forces Hospital, Brasília-DF, Brazil

Recepción: 30 de octubre de 2012

Aceptación definitiva: 21 de noviembre de 2012

\section{Correspondencia:}

Vitorino Modesto dos Santos

Hospital das Forças Armadas

Estrada do contorno do bosque, $\mathrm{s} / \mathrm{n}$

Cruzeiro Novo, 70658-900

Brasilia-DF

E-mail: vitorinomodestos@gmail.com 


\section{INTRODUCTION}

Gastrointestinal lipomas more frequently occur in the colon (60-75\%) and the small intestine (up to $31,2 \%)^{1-7}$ Only $5 \%$ of them are found in the stomach, which accounts for less than 1\% of the gastric tumors, and $2 \%$ to $3 \%$ of benign tumors of this organ ${ }^{2,4-10}$. They can be under recognized or misdiagnosed by more common masses $^{5}$ like gastrointestinal stromal tumor, leiomyoma, fibroma, neurilemmoma, adenomyoma, Brunner's gland adenoma, and heterotopic pancreas ${ }^{2}$ The first description of gastric lipoma is attributed to Cruveilhier (1842) ${ }^{8}$. There are only about 220 cases of gastric lipomas described in the literature ${ }^{2,5,8}$ around $10 \%$ are intramural or subserosal, while the vast majority have origin in the submucosa $\mathrm{a}^{5,7-10}$ The etiology of lipoma remains unknown ${ }^{2,6,8}$ and it may constitute an acquired condition or an embryological misplacement ${ }^{6}$ The tumor is constituted by well differentiated adipocytes with a fibrous capsule, and if sectioned it grossly appears as an yellowish tissue $^{2,3,5,7,10}$ Although more commonly located in the gastric antrum $(75 \%)^{2}$ these tumors may be found at any site of the stomach $^{4-10}$ Gastric lipoma is a rare benign condition, which may mimic malignancy of the stomach.

\section{CASE REPORT}

A 51-year-old Brazilian woman was admitted because of a severe epigastric pain associated with episodes of vomiting, dyspepsia, dysphagia and weight loss of $5 \mathrm{~kg}$ during 8 months. Her body mass index was $19.81 \mathrm{Kg} / \mathrm{m}^{2}$, and the routine laboratory determinations were unremarkable. She underwent three endoscopy studies that disclosed an antral mass with around $3 \mathrm{~cm}$ (Fig. 1A-B). PET/ CT images revealed a spherical hypoattenuating mass (31 mm x $20 \mathrm{~mm}$ ) with fat density, without enhanced metabolism, at the antrum; and the ecoendoscopy study found a submucosal homogeneous hyperecogenic mass (27 mm x $20 \mathrm{~mm}$ ) on the same site. The specimens obtained from two routine endoscopic biopsies revealed normal mucosa. Another biopsy was performed - guided by endoscopic ultrasound, and revealed mature fat tissue at the submucosa, and diagnosis of submucosal lipoma was characterized (Fig. 1C-D). She underwent an atypical gastrectomy by laparoscopic route, and employing linear staplers (Fig. 2A-B) to remove the gastric mass along with a wide free surgical margin. Grossly, the aspect of transected tumor was yellow and adipose (Fig. 2C-D), with a capsule. On the fifth postoperative day, the patient presented with vomiting and dysphagia, and the endoscopic evaluation revealed a pyloric substenosis, corrected by dilation. After an uneventful evolution, she was discharged to home; nevertheless, five days later, she claimed of anorexia and recurrent vomiting, and another endoscopy detected pyloric obstruction. Therefore, the patient was submitted to a pylorotomy, and was discharged to outpatient surveillance on the third postoperative day, asymptomatic and accepting solid foods.

\section{DISCUSSION}

This 51-year-old female presented with clinical features typical of gastrointestinal obstruction and her age was in accordance with the mean age of patients at diagnosis of gastric lipomas ${ }^{5,8}$ However, no specific symptoms could hardly contribute to raise suspicion about gastric lipoma, and the final diagnosis was based on imaging investigation and further histopathology studies. The upper digestive endoscopy showed a submucosal mass measuring about $3 \mathrm{~cm}$ in diameter. The first two biopsy procedures did not furnished enough tissue to histopathology analysis, phenomenon that is frequently reported in literature ${ }^{3-5,8,9}$ The tissue samples from the third biopsy, which was guided by endoscopic ultrasound, revealed the origin of the tumor - a classical lipoma. Surgical approach was done, as most of the authors recommend for symptomatic patients ${ }^{3-5,7-9,11}$ The occurrence of pyloric stenosis was an expected complication of the atypical gastrectomy, because the tumor resection was performed at the antrum, and with a large free surgical margin. Gastric lipomas predominate in people over than 50 years of age $\mathrm{e}^{2,5,8,11}$ and appear as solitary and asymptomatic masse ${ }^{5-10}$ However, patients with gastric lipomatosis have been reported as an exceeding rare condition ${ }^{12}$ The symptoms depend on localization and size of the tumor and of associated entities ${ }^{2,7-10}$ Those lipomas de- 


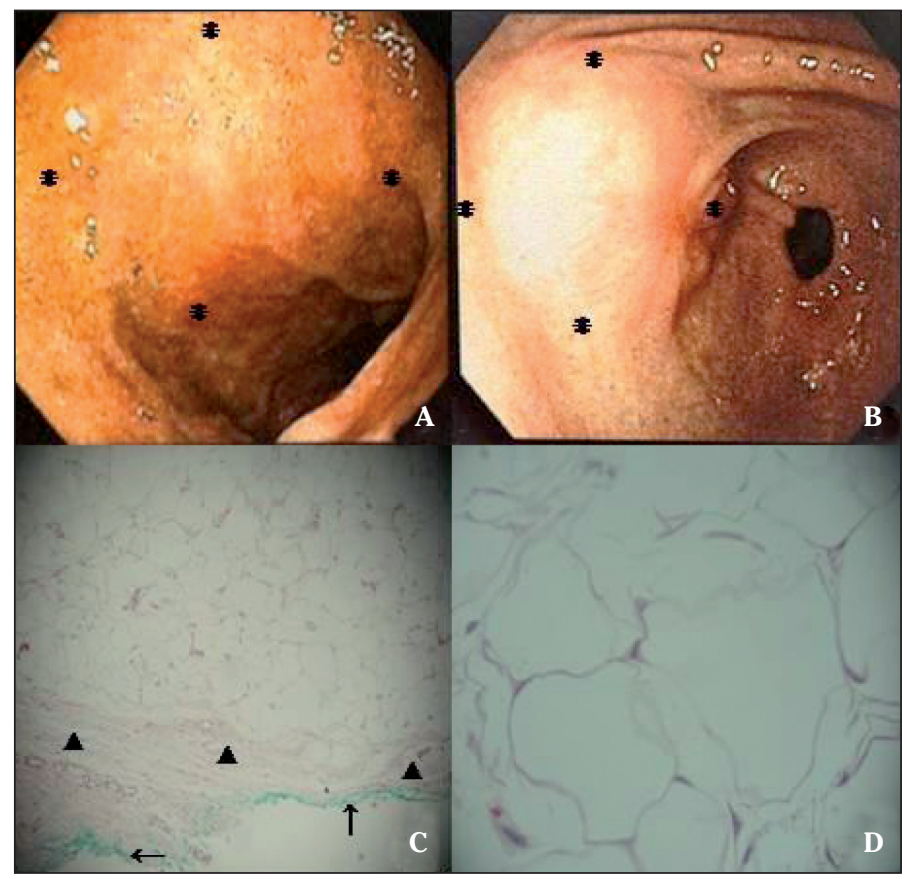

D
Figure 1. A and B: Endoscopy view of the submucosal antral mass (asterisks), measuring around $3 \mathrm{~cm}$ of diameter; $\mathbf{C}$ : Photomicrography of gastric sample, showing normal mucosa (arrows) and mature fat tissue typical of lipoma on the submucosa (arrowheads); D: Sample of lipoma in a high magnification view.
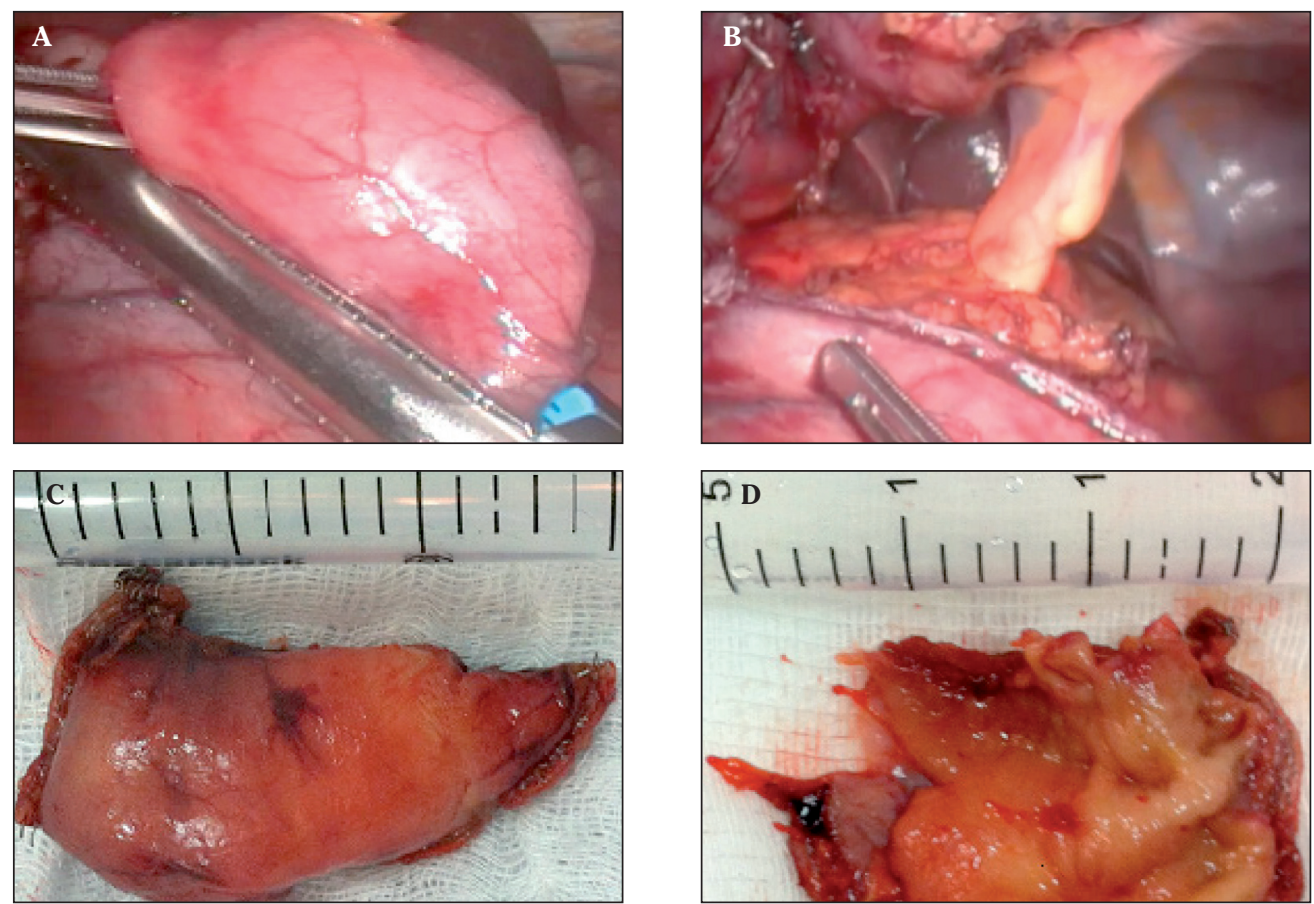

Figure 2. A and B: Gastrectomy done by laparoscopic route, and using linear staplers to remove the submucous lipoma with a wide surgical margin; $\mathbf{C}$ and D: Gross aspect of the transected tumor, which appears yellow and adipose, surrounded by a capsule. 
veloped at the antrum and the body of the stomach may origin intussusceptions into the pylorus causing obstruction and pain; while voluminous tumors may be associated with venous stasis, resulting in ulceration and hemorrhage ${ }^{6-10}$ Lipomas larger than $2 \mathrm{~cm}$ usually cause symptoms (diarrhea, obstruction, intussusception, hemorrhage $)^{2,4,5,7,10}$ The most common symptoms are dyspepsia, epigastric pain, upper gastrointestinal bleeding (usually by ulceration and necrosis), obstruction and intussusception $^{3-11}$ Because of the absence of symptoms, in the vast majority of cases gastric lipoma constitutes an endoscopic finding $3,5,6,8,10$ and the tumor often appears as a smooth, yellowish submucosal mass with or without ulceration ${ }^{3-5,10}$ Classical imaging aspects like "tenting", "cushion sign" and "naked fat sign" are useful to diagnose submucosal lipomas. ${ }^{2-7,11}$ To perform a successful endoscopic biopsy of submucosal lipomas can be a challenging $\operatorname{task}^{2,4,5,9}$ In general, these biopsies only reveal a normal gastric mucosa $a^{2,3,6,8,9}$. The use of electrocautery to elicit a local mucosal ulceration, before the biopsy procedure, might be of some utility ${ }^{5}$ Computerized tomography (CT) is a highly specific tool that can contribute to diagnosis s $^{23-9,10}$ In CT images, the lipoma typically appears as a mass that is isodense $(-70 \mathrm{H}$ to $-120 \mathrm{H})$ with fat t $^{3,4,6,7,9,10}$ Endoscopic ultrasound is useful to diagnosis of gastric lipoma, showing the hyperecoic density of the tumor in the submucosa $\mathrm{a}^{2,3-10}$ Gastric lipomas do not have malignant potential ${ }^{2,4-6,9}$ however, synchronous gastric carcinomas have been very rarely described ${ }^{6,9}$ Treatment of gastric lipoma, is controversial ${ }^{4,9}$ but resection is the best choice for symptomatic tumors ${ }^{2-5,8,10}$ Laparoscopic route is used for tumors up to $6 \mathrm{~cm}$ in diameter ${ }^{2,7}$ Pedunculated lipomas smaller than $3 \mathrm{~cm}$ may be excised by upper digestive endos- copy route $e^{4,7,8,11}$ but mere observation is an alternative $e^{2,4,7,10,11}$ Hemorrhages can be treated by endoscopic clipping ${ }^{5}$.

\section{REFERENCES}

1. Calvo AM, Montón S, Rubio T, Repiso M, SaraSIBAR H. Invaginación intestinal en el adulto secundaria a lipoma yeyunal. An Sist Sanit Navar 2005; 28: 115-118.

2. Neto FA, Ferreira MC, Bertoncello lC, Neto AA, De Aveiro WC, Bento CA et al. Gastric lipoma presenting as a giant bulging mass in an oligosymptomatic patient: a case report. J Med Case Rep 2012;6:317.

3. Penston J, Penston V. Gastric lipoma: a rare cause of iron-deficiency anaemia. BMJ Case Rep 2009; 2009. pii: bcr09.2008.0954. Epub 2009 Mar 24.

4. Sadio A, Peixoto P, Castanheira A, Cancela E, Ministro P, CAsimiro C et al. Gastric lipoma - an unusual cause of upper gastrointestinal bleeding. Rev Esp Enferm Dig 2010: 102: 398-400.

5. Saltzman JR, Carr-Locke DL, Fink SA. Lipoma case report. Med Gen Med 2005; 7: 16.

6. Yamamoto T, Imakirre K, Hashiguchi S, Matsumoto $\mathrm{J}$, KAdONO J, Hamada $\mathrm{N}$ et al. A rare case of gastric lipoma with early gastric cancer. Intern Med 2004;43: 1039-1041.

7. Zameer M, Kanojia RP, Rao KL, Menon P, Samujh R, Thapa BR. Gastric lipoma. J Indian Assoc Pediatr Surg 2010; 15: 64-66.

8. Kim DD, Tsai AI, Otani AR, Puglia CR, Malheiros CA. Lipoma gástrico: case report. Rev Col Bras Cir 2011; 38: 205-206.

9. Krasniei AS, Hoxha FT, Bicaj BX, Hashani SI, Hasimja SM, Kelmendi SM et al. Symptomatic subserosal gastric lipoma successfully treated with enucleation. World J Gastroenterol 2008; 14: 5930-5932.

10. Thompson WM, Kende AI, Levy AD. Imaging characteristics of $g$ 10. DONE HJ. Lipoma of the stomach. Br Med J 1961; 1: 183.

11. Bijlani RS, KulKarni VM, Shahani RB, Shah HK, Dalvi A, SAmsi AB. Gastric lipoma presenting as obstruction and hematemesis. J Postgrad Med 1993; 39: 42-43. 